\title{
Role Optimization of Indigenous Institutions for Case of Violence Against Women and Children (Analysis Study in Aceh and Padang Provinces)
}

\author{
${ }^{1}$ Husaini Husda, ${ }^{1}$ Zubaidah

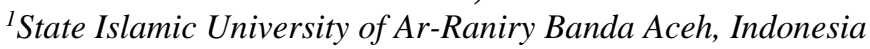 \\ ernitadewi143@gmail.com
}

\begin{abstract}
Institutions as social control always succeed in regulating so that the social life of citizens can run in an orderly and smooth manner in accordance with prevailing traditions and norms. As has been functioning well in the past, both in Aceh and West Sumatra. Aceh with its gampong pageu, and West Sumatra with surau. Both reflect a blend of local wisdom (adat) and Islamic values in it. However, if you see the rampant cases of violence and sexual abuse that have occurred in women and children lately, it is not wrong to say that the role of institutions as social control began to weaken. Like the role of surau and gampong pageu which is slowly ignored and forgotten. Re-empowering social institutions means trying to restore the pattern of community behavior based on existing norms. For this reason, systematic efforts are needed in empowering social institutions by empowering social institutions in accordance with the changes and demands of the times.
\end{abstract}

Keywords: Social Institution, Pageu Gampong, Aceh, Surau, Padang, Minangkabau, The Protection of Women and Children.

\section{Introduction}

The report of the National Commission on Violence Against Women (Komnas Perempuan) collected from various service institutions in Indonesia from 2001 to 2012 recorded a total of 3,169 to 216,156 cases of KTP (Violence Against Women) each year with a tendency to increase from year to year. ${ }^{1}$ What is equally heartbreaking is that when reports of violence occur in children, these cases are dominated by cases of sexual abuse. The current sexual harassment is increasing in percentage, as is the case in Aceh. The Legal Aid Institute (LBH) of Aceh Children recorded 149 cases of sexual violence / abuse for children in Aceh that occurred throughout 2010 to 2014. Cases of violence / sexual abuse of children in Aceh increased every year in 2010, 27 cases; in 2011, 29 cases; 2012, 32 cases; in 201326 cases and in 2014 there were 35 cases. $^{2}$

These numbers are only recorded based on the report. In 2014, UNICEF reported that 1 in 10 girls was sexually abused. This data may not be fully believed, because sexual harassment makes abused people uncomfortable to report so that there is still a lot of sexual harassment not reported. Therefore, harassment behavior is not well recorded, both in legal institutions and community social institutions. ${ }^{3}$

\footnotetext{
${ }^{1}$ Kristi Poerwandari, Peta Kekerasan: Pengalaman Perempuan Indonesia, (Komnas-Perempuan, Jakarta, 2002), page. 46, 50-91.

${ }^{2}$ Serambi Indonesia, Tuesday, November $25^{\text {th }} 2014$

${ }^{3}$ Syaiful Bahri dan Fajriani, "Suatu Kajian Awal Terhadap Tingkat Pelecehan Seksual di Aceh", in Jurnal Pencerahan, Vol. IX, No. 1, (2015), page. 50.
} 
Barriers experienced by victims when accessing justice through formal mechanisms, among others: the inability of formal institutions at the police level in responding to victims' complaints; victims experience layered discrimination because of the lack of understanding of gender-based violence by law enforcement officers. The police often facilitate mediation between victims and perpetrators, especially in domestic violence cases, whereas not all offenses in domestic violence cases can be resolved through mediation forums (not criminal complaints but pure criminal offenses). ), only based on revocation of reporting by victims. ${ }^{4}$

Seeing the facts above the existence and role of the companion institution becomes very important, not only as a legal accompaniment, but also providing counseling and recommendations for referral of victims' recovery. ${ }^{5}$ Islam greatly glorifies women and children, there are many texts that support this statement and the application of this fact in the course of history there are several social institutions from various groups in society in Indonesia that greatly glorify women and child groups. However, it cannot be denied the role of social institutions which are expected to be able to regulate the social life of the community in order to run in an orderly and smooth manner in accordance with certain rules, in general it does not run optimally.

In Aceh and West Sumatra, in the culture and structure of the Acehnese society, cultural values stem from Islamic values. Indigenous ngon hukom (religion), but the substance ngon sifeut, meaning that Aceh's traditional values are integrated with religious values. ${ }^{6}$ This is reflected in one of the social institutions of the Acehnese community known as the gampong pageu. West Sumatra is also known as Adat Basandi Syara ', Syara' Basandi Kitabullah (ABS SBK), Syara 'mangato, Adat mamakai. This philosophy has confirmed the existence of Islam in social life in its community, and become an inseparable thing in their daily lives. These values apply in various institutions, such as surau, family institutions (rumah gadang) and other institutions.

Based on the importance of the role of social institutions, but collided with the attitude of the people who began to ignore the existence of social institutions, this paper seeks to get concrete answers to this problem, especially to strengthen the role of social institutions to become a protective shield for the security of women and children, especially in Aceh and Padang.

\subsection{Social Institutions in Aceh Province}

\section{Review of Literature}

Social institutions arise and develop as a reflection of a human culture which, according to Kluckhom, as quoted by Naskur ${ }^{7}$, is the whole way of human life. The same thing was stated by Yusran that social institutions are closely related to human culture because institutions

\footnotetext{
${ }^{4}$ Komnas Perempuan, Mewujudkan Perlindungan Perempuan Korban melalui Pemenuhan Bantuan Hukum: Kertas Posisi Terhadap Pembahasan RUU Bantuan Hukum. See www.komnasperempuan.go.id/

${ }^{5}$ See Arimbi Heroepoetri (peny.), Pengetahuan Hukum Sebagai Penberdayaan Hukum Perempuan: Hasil Pemantauan Akses Perempuan pada Keadilan, (Jakarta: Komnas Perempuan, 2011), p. 41.

${ }^{6}$ Badruzzaman Ismail, Peranan Adat Aceh Mendukung Bangsa yang Berdaulat, see in http://maa.acehprov.go.id/?p=979 accessed on April 27th 2017.

${ }^{7}$ Naskur, "Hukum Islam dan Pranata Sosial: Sebuah Kajian Makna Teks Nash", in Jurnal al-Syir'ah, Vol. I, No. 2, (2003), page. 6-7.
} 
themselves mean a system of official social behavior in the form of customs and norms that govern behavior and all its equipment for various complex human beings in society. Thus, in general it can be formulated that social institutions are traditions in human life that are formed as a combination of human reaction to the challenges and dynamics of the environment, with ethos which is the basic value of life for Muslims, and the value of the ethos is formed from the teachings the basis developed by the Qur'an and the Sunnah.

In the life of the Indonesian Islamic community today, in particular it is known as an Islamic social pattern. The institutions cover various fields of life that are constantly evolving from time to time. There are institutions that are very close to the beliefs that are followed, so that they have a very high level of sensitivity, such as worship institutions, kinship institutions and educational institutions. There is also a relatively far from belief, so it is relatively flexible or "neutral" like an economic institution. Furthermore, the institution experienced concretization in the structure of society in the form of various social organizations as a vehicle for meeting life's needs in a collective and planned manner.

Islam is present in the archipelago not in a culture of empty society. Cultural practices are accommodated and adopted and then Islamized. Islam does not displace the culture that lives in a society where Islam comes to enlighten the faith of the Ummah. Islam straightens out, gives value, meaning and reinforces the culture that has lived for a long time in the one society that it is preaching. ${ }^{8}$ Aceh and Padang became two archipelago regions where Islamic values became an integral element in people's lives. Society, culture (adat), and religion (Islam) go hand in hand to form a unified whole that displays the distinctiveness seen in life that takes place in Aceh and Padang.

In his writing, Hoesein ${ }^{9}$, Acehnese people have a philosophy of life which is an integration between hukom ngon adat (religion and adat) as found in the hadih majah (proverb) of hukom ngon Adat lagee zat ngon sipheut ([religious] law and adat like substance and character, inseparable). Sumardi ${ }^{10}$ added another story; hukom meunyo hana adat tabeue, adat meunyo hana hukom bateue (law if without bland customs, custom if no law is canceled). It can be understood that between Islamic culture and teachings have interacted and assimilated harmoniously in the Acehnese society for hundreds of years. Concrete forms of adat and culture in the lives of Acehnese people are not only applied in the social, economic and political fields, but also in the legal field. ${ }^{11}$

Pageu gampong is part of a social institution or management structure in the community at the village level (gampong), which has the authority to oversee regulations at the village level. This social institution can increase the role of community control to care for each other. In carrying out customary justice in Aceh there are several principles emphasized therein, namely

\footnotetext{
${ }^{8}$ Abidin Nurdin, "Integrasi Agama dan Budaya: Kajian Tentang Tradisi Maulod dalam Masyarakat Aceh", in Jurnal el-Harakah, Vol. XVIII, No. 1, (2016), page. 46.

${ }^{9}$ Moehammad Hoesein, Adat Atjeh, (Banda Aceh: Dinas Kebudayaan Provinsi Daerah Istimewa Aceh, 1970), page. 1.

${ }^{10}$ Rusjdi Ali Muhammad dan Dedy Sumardi, Kearifan Tradisional Lokal: Penyerapan Syariat Islam dalam Hukum Adat Aceh, (Banda Aceh: Dinas Syariat Islam, 2011), page. 37.

${ }^{11}$ Abidin Nurdin, "Revitalisasi Kearifan Lokal Aceh: Peran Budaya dalam Menyelesaikan Konflik Masyarakat", in Jurnal Analisis, Vol. XIII, No. 1, (2013), page. 139.
} 
those who are weakly guided, those who are crippled are carried out, those that are less added, those that are oddly fulfilled, those that are wrongly corrected, those who are forgotten are reminded, those who are crying are ignored, those who fight are confused, and those who are wrong be reminded. ${ }^{12}$

The management structure at the village level is usually borne by the Geuchik who is also accompanied by Imam Meunasah, along with other village officials such as Tuha Peut, Chair of the Hamlet, and Tuha Lapan. In the problem solving system, every problem that is always prioritized is resolved internally. In a sense, as much as possible within the scope of the family by prioritizing deliberations and carrying out solutions to problems in a peaceful way and wherever possible prioritize justice for the victims, especially for women and children. If the meeting point for resolving the problem is not found, then the cases will be the responsibility of the authorities.

The village government structure, namely Geuchik, Tuha Peut, Tuha Gampong, Teungku Imum, is a form of social institution embodiment which has a role to maintain social welfare in its own environment. Where various problems that occur, will be resolved through the village government structure earlier. Even the authority of the village apparatus to solve problems is stated in the village government Qanun.

The village government is a formal symbol of village community unity. Village government has a significant role in managing social processes in the community, one of its tasks is to provide good social services so that they can bring their citizens to a life that is prosperous, peaceful and just. So naturally, the orderliness, tranquility and security of the village community rests on every tool in the village administration, which clarifies the position of the village apparatus as a manifestation of the social institutions in the villages in Aceh.

\subsection{Social Institutions in Padang}

For Padang, in the historical trajectory, social institutions function optimally through traditional institutions, such as surau, lepau, custom density and existing social structures. ${ }^{13}$ Indigenous Philosophy Basandi Syara, Syara' Basandi Kitabullah (ABS SBK), Syara 'mangato, Adat mamakai is reflected in the function of surau which is run as a social institution. The social and cultural life of the Minangkabau people developed in Surabaya because the religiosity of the Minangkabau people cannot be separated from their daily lives. Surau or musalla / mosque in the wider community, is not only used for places of worship, but in the Minangkabau surau community has a considerable role such as learning about religion, morals, pantun, randai and other Minangkabau cultural customs even in surau also the place of personal formation of successors generation of Minang who are ready to bear the burden and mandate later on.

Surau according to the Minangkabau traditional pattern as stated by Sidi Gazalba belongs to the people or Indu.

\footnotetext{
${ }^{12}$ Badruzzaman Ismail, Masjid dan Adat Meunasah Sebagai Sumber Energi Budaya Aceh, (Banda Aceh: Majelis Adat Aceh Provinsi Nanggroe Aceh Darussalam, 2007), page. 164.

${ }^{13}$ Dr. Efrinaldi, dari Kelompok Studi Islam, Masyarakat dan Adat Minangkabau.
} 
Surau was established as a complement to a nagari that functions as a meeting place, gathering and overnight for young people and elderly parents who are already old. ${ }^{14}$ Azyumardi Azra further argued that surau functions as a meeting place, gathering place and bed for boys who are already illiterate and elderly parents. This is very closely related to the customary provisions, that boys do not have rooms in the gadang house in their parents' homes, while the rooms in the Gadang house are for girls. ${ }^{15}$

Thus it can be said, that surau is a place of customary socialization processes and as an educational institution for the younger generation and Minangkabau people in general. Besides that, an adult man does not have a room in his parents 'house, as well as a man who is old or divorced by his wife does not return to his parents' house, but must live in surau. It is precisely that men in Minangkabau in terms of function have an important position in the family, but "poor" in terms of residence.

So it is not wrong to say that Surau is one of the social institutions in the Minangkabau community. Surau concerns its function as one or part of the important institutions in the Minangkabau community, has played its role to fulfill various needs of the community in social life in the community. Just mention the function of Surau as an educational and teaching institution for teenagers in Minangkabau, besides that Surau also plays its function in the dissemination of various information that must be known to the public. ${ }^{16}$

In addition, Minangkabau adheres to a matrilineal kinship system. Therefore, in socioculural analysis, women have a central and vital role and position. ${ }^{17}$ Social life in Minangkabau is governed by adat based on networks; mamak kem ni, and women called Bundo Kanduang are centered on mothers in the gadang house who run the nagari government which is based on 3 (three) systems of relations: mind and stamps; groove and patuik (groove and proper); anggo jo tanggo, which has been determined by adat.

Mamak is a status that is also an institution, given to men in the mother's family; namely mother's brother; father, next to mother; and the son of the mother's family. Mamak (uncle) as one of the social institutions in Minangkabau has the duty to be able to safeguard the child from being harmed by social irregularities. In Minangkabau mamak is highly respected because religious and social issues are very much dependent on the role of the mamak. ${ }^{18}$

\subsection{Functions of Social Institutions in the Community}

Santosa ${ }^{19}$ in his writing explained that the creation of social institutions basically had the purpose and objectives which were not principally different from social norms, because basically

\footnotetext{
${ }^{14}$ Sidi Gazalba, Mesjid Pusat Ibadat dan Kebudayaan Islam, Cet. V, (Jakarta, Pustaka al-Husna, 1989), page. 315.

15 Azyumardi Azra, Surau Pendidikan Islam Tradisonal dalam Transisi dan Modernisasi, (Ciputat: Logos Wacvana Ilmu, 2003), page. 8.

${ }^{16}$ Endah Wulan Sari, Surau dan Kehidupan Sosial Budaya Minangkabau, dalam http://wawasanproklamator.com/artikel/30/surau-dan-kehidupan-sosial-budaya-minangkabau.html accessed on June $9^{\text {th }} 2018$, at: 18:12 WIB.

${ }^{17}$ Dr. Taufiqurrahman, dari Kelompok Studi Islam, Masyarakat dan Adat Minangkabau.

${ }^{18}$ Dra. Sismarni, M.Pd. Salah satu dosen di Fakultas Adab dan Humaniora Universitas Islam Negeri Imam Bonjol, Padang.

${ }^{19}$ Agus Santosa, Pranata Sosial: Pengertian, Tipe dan Fungsi, (2009), page. 4.
} 
social institutions were a set of social norms. In general, the main purpose of social institutions, in addition to regulating so that the needs of human life can be fulfilled adequately, also at the same time regulate so that the social life of the citizens can run in an orderly and smooth manner in accordance with the applicable rules.

The existence of social institutions as part of the social control system in the community, usually differs according to the characteristics of the community which is a local wisdom that is highly respected by every member of the community. the aim is that the community members adhere to the agreed upon norms, so that they live in an orderly, safe and orderly manner, because basically people have a desire to live in an orderly, safe and orderly manner. However, each individual has their own position, not even in his view of orderly, safe and orderly life. Therefore, to maintain the balance of each individual's position, a behavior guideline called norms or rules is needed. ${ }^{20}$

The norms or rules according to Soekanto as quoted in Husda ${ }^{21}$, are standards, boundaries or guidelines for expected behavior or behavior. Broadly speaking these norms can be distinguished into rules of trust, decency, politeness and law. If there are norms in society, then to ensure their implementation, a strengthening and enforcement mechanism is needed called a system of resilience and social control.

For example, it can be seen in Aceh, since a long time ago many problems have been resolved in people's lives that were resolved through norms or rules in the Customary Court. The legal basis for the establishment and empowerment of Customary Courts in Aceh is supported by a number of laws and regulations as a legal umbrella. ${ }^{22}$ These regulations and legislation are described using the phrase "Customary Institution", this customary institution can be realized through the embodiment of social institutions as a gampong pageu (village fence). ${ }^{23}$ Pageu gampong is part of a social institution or management structure in the community at the village level (gampong), which has the authority to oversee regulations at the village level.

\subsection{Protection of Women and Children}

\section{Discussion}

In Aceh most of the cases involving women as victims were cases of domestic violence. Problem solving is usually taken through media consultations involving all village officials, starting from the Geuchik, Tuha Peut, Tuha Lapan, and Teungku Imum. In the process of resolving this domestic violence problem, the perpetrators (husbands) and victims (wives) will be mediated to reconcile and reconcile so as not to arrive at the divorce. Usually, in the mediation process, the perpetrators of violence the perpetrators of violence will be asked to sign

\footnotetext{
${ }^{20}$ Husaini Husda, "Identifikasi Kearifan Lokal: Sistem Ketahanan dan Pengendalian Sosial Masyarakat di Kabupaten Nagan Raya”, dalam Jurnal Adabiya, Vol. IX, No. 17, Agustus 2007, (Fakultas Adab IAIN Ar-Raniry, Darussalam-Banda Aceh, 2007), page. 24.

${ }^{21}$ bid. Lihat pula Soerjono Soekanto, Pokok-pokok Sosiologi Hukum, (Jakarta: Rajawali Press, 1983$)$, page. 67.

${ }^{22}$ Undang-undang No 44 Tahun 1999; Qanun Provinsi Aceh No 4 \& 5 Tahun 2003, No 11 Tahun 2006 , No 9 \& 10 Tahun 2008.

${ }^{23}$ Mahdi, "Eksistensi Peradilan Adat di Aceh”, in Hunafa journal, Vol. 8, No. 2, (2011), page. 192.
} 
the perpetrators of violence will be asked to sign a kind of statement declaring themselves not to repeat the same actions. ${ }^{24}$

The settlement mechanism starts with reports from the victim to the village officials, which will be followed up according to the level of the problem. If there are problems, but not until the report, usually the local Kadus will come to the victim, with the intention of finding out the problem and trying to mediate. From here Kadus will give a report to the Geuchik, which will be held in consultation with the other village officials and the victims and the perpetrators involved in the disputes.

In deliberations, in addition to the village apparatus mentioned above, it also involves women leaders in solving problems, especially those related to women's empowerment and protection. The position of female leaders in each village is very important, because, when there are cases of violence against women, victims will be more open and free to tell about the events they experienced, than with other village officials who are not men. With the courage to report, the problem will be followed up so that the victims get justice. ${ }^{25}$

The involvement of female leaders in the village apparatus structure is a form of village concern for women. For example, when there is a problem of violence that makes women victims, solving problems also requires a perspective and opinions of women, represented by female leaders in the structure of the Tuha Peut. Thus, it is hoped that there will be no women's rights in obtaining the justice and defense that have been missed. ${ }^{26}$

However, here the role of the village apparatus is not as a determinant of who is wrong and who is right. Village officials are only facilitators who try to mediate, resolve and reconcile any problems that occur in the village, such as domestic violence cases. Because the first priority for resolving cases is how both parties (perpetrators and victims) can make peace. However, if after the mediation process does not arrive at the same agreement, namely reconciliation, then with a statement from the village, the case will be delegated to a higher level in the sub-district. ${ }^{27}$

In solving the problem of violence against women and children at the village level, ${ }^{28}$ Aceh customary law provides privileges, that the case is not resolved openly by involving many people, but this case is resolved in a closed manner by sending two village leaders to the scene of the case, or calling warring parties, to be resolved in an undisclosed location. Usually cases involving women, especially domestic violence, are handled carefully and consider the shame or disgrace of people who are experiencing problems. Then try as much as possible so that the case is not known to the public. The advisors and mediators are selected from the village apparatus really capable to solve problems.

There are also villages whose village officials do not wait for reports from the parties concerned, so if the news of violence reaches the Geuchik, Tuha Peut or other village apparatus, through rumors of the surrounding community, not through a report from the victim, the

\footnotetext{
${ }^{24}$ Mansurdin, Sekretaris Desa, Desa Blanggelinggang Kecamatan Sawang Aceh Selatan. The interview was conducted on July $6^{\text {th }} 2018$.

${ }^{25} \mathrm{bid}$.

${ }^{26}$ Syarifuddin, Imam Chiek, Desa Blanggelinggang Kecamatan Sawang Aceh Selatan. The interview was conducted on July $6^{\text {th }} 2018$.

${ }^{27} \mathrm{bid}$.

${ }^{28}$ The interview was conducted on July $5^{\text {th }} 2018$
} 
apparatus the village will immediately take action by calling on both parties involved in the dispute, namely the perpetrator and the victim. The problem solving process will usually be carried out in the Geuchik office, starting with finding out the root of the problems that occur, so that there is no defense to the side. ${ }^{29}$

With the gampong pageu, every problem that exists is always prioritized to be resolved internally. In a sense, as much as possible within the scope of kinship by prioritizing deliberations and carrying out solutions to problems in a peaceful way and wherever possible prioritize justice for the victims, who are women and children.

If the meeting point for resolving the problem is not found, then the cases will be the responsibility of the authorities. In essence, social institutions in every region, especially Aceh, still continue to strive to carry out their functions in carrying out social control in the community, despite all the shortcomings, challenges and obstacles faced.

\subsection{Roles of Social Institutions: Past and Present}

The developments and changes that continue to occur over time also lead to changes in every social structure that exists in society. There are those who are getting stronger, there are those that are weakening, fading even slowly forgotten by the people. This is what happens in the existence of social institutions in the midst of society. In fact, this social institution is an important part of the realization of a controlled and controlled community life in accordance with the norms that have developed in each region. As a result, it can be seen from current patterns of community behavior that tend to be oriented towards negative or deviant things. The large number of young people caught in drugs, student brawls, violence and sexual harassment that continue to consume victims, is a picture of a system of social control that no longer functions in the community.

One of the causes of the waning role of social institutions in society in Indonesia, in this case especially in Aceh, is due to the enactment of regulations from the Government since 1971, where the Central Government issued Presidential Decree Number 81 of 1971 concerning Village Social Institutions. This regulation has been designed since 1969. With the hope that rural communities will be more optimal in taking a role in building their welfare more independently.

After more than 10 years of this regulation, the hope was still not maximized by the rural community, so the Central Government issued a new regulation, namely Presidential Decree No. 28 of 1980 dated March 31, 1980 concerning the Organizational Structure and Work Procedure of Village Resilience Institutions (LKMD) The Village Community Resilience Institute (LKMD) is the only community institution formed by the government at the village or kelurahan level and its relationship with the government is non-structural. This institution was formed with the function of assisting village or kelurahan government in the field of development planning, mobilizing community participation to carry out integrated development and developing dynamic conditions of the community in the context of village resilience.

\footnotetext{
${ }^{29}$ Wawancara H. Taslim selaku Kepala Desa di Desa Hilir Kecamatan Tapak Tuan, Kabupaten Aceh Selatan. The interview was conducted on July $5^{\text {th }} 2018$.
} 
The weakness of the two regulations stipulated by the government is that they are very foreign to parts of Indonesia by not accommodating existing social institutions models and developing hundreds of years back in people's lives. So that these regulations then turn off existing social institutions as local wisdom in various regions in Indonesia, not least in the Provinces of Aceh and West Sumatra.

For this reason, efforts to re-function the role of social institutions in society are very important. As in Aceh, the pursuit of programs to strengthen traditional justice actors (pageu gampong) continues. Like the gampong pageu which is actually not something physical. In that sense, the meaning or concept of the gampong pageu is not attached to the structure, but to the system it carries. This was confirmed by Abdurrahman, one of the members of the Aceh Adat Assembly (MAA) ${ }^{30}$ for almost 14 years. Pageu gampong is a social institution that also functions as a traditional institution in the community. Which in it adheres to a protective system, which is carried out to maintain order and order in people's lives.

The protective system in the gampong pageu, according to Abdurrahman, contains two elements. First, the element of prevention. This preventive element is intended as a process, method, preventive action or action to prevent something from happening. In this element, actors who have customary authority in implementing the element of prevention and implementing village gangs can be seen in terms of culture and structure. Which, according to Abdurrahman, these two aspects need to be constantly optimized for its functions and roles in society. In terms of culture, the precautionary responsibility is attached to the ureung chik, which includes grandfather, father, uncle, grandmother, abua, and all that is predicted in Acehnese customs. In addition, there are also "people", these people can have a relationship of kinship / blood ties, it can also have no blood ties, but can be tied to moral and inner attachments. So, social safeguards or supervision carried out by actors from cultural aspects of the village gampong are obligations that are based on adat.

\section{Conclusion}

Social institutions have a function as social control in people's lives. For Aceh, one of the social institutions that is owned is the gampong pageu, which consists of the Geuchik which is also accompanied by Imam Meunasah, along with other village officials such as Tuha Peut, Chair of the Hamlet, and Tuha Lapan. In the problem solving system, every problem that is always prioritized is resolved internally. In a sense, as much as possible within the scope of kinship by prioritizing deliberations and carrying out solutions to problems in a peaceful way and wherever possible prioritize justice for the victims, who are women and children.

The obstacle in handling cases that make women and children victims is the absence of reports from the victims. In some villages in Aceh, there are still many cases of sexual violence and harassment that afflict women and children that pass away without any problem solving because there are no reports from the victims. Whereas the problem solving mechanism can only be processed if the victim's report arrives to the village apparatus. The reluctance to report

\footnotetext{
${ }^{30}$ This institution works to strengthen Customary Leaders (Indigenous Leaders) to develop Customary Courts in Aceh
} 
usually occurs because of shame, some do not know where and how to complain, and the inconvenience to tell or complain.

In this case, the role of female leaders as gampong officials in traditional institutions is a very crucial role. Because, in order to be able to narrate and describe the chronology of the occurrence of violence and sexual abuse certainly requires unusual courage, the listener must be able to present a comfortable and calming feeling that can make the victim believe and free to tell stories. Of course, in this case women who naturally and naturally have the character, personality, motherly figure who is gentle, loving, patient, and able to be a good listener, more needed for her role to attract victims to be willing to tell stories about violence or harassment that befell him. However, based on fieldwork, there are still many areas in Aceh that do not involve the role of women in village-level government structures. For this reason, the media for the delivery of various community problems, especially cases of violence and sexual harassment, should be a concern to be presented, strengthened, and maximized.

As with Padang, in the historical trajectory, social institutions function optimally through traditional institutions, such as surau, lepau, custom density and existing social structures. Surau has a strategic function, such as learning about religion, morals, rhymes, randai and other Minangkabau cultural customs even in surau, also the place for the personal formation of the successor of the Minang generation who are ready to bear the burden and mandate later on. However, the role of traditional institutions began to weaken over time. For example, the decline in the role of surau was inseparable from the decline of the role of the upper house, ninik mamak and bundo kanduang in fostering their personal care of their children. In addition there is an assumption that the surau education system is outdated.

\section{References}

Abidin Nurdin, "Integrasi Agama dan Budaya: Kajian Tentang Tradisi Maulod dalam Masyarakat Aceh", dalam Jurnal el-Harakah, Vol. XVIII, No. 1, (2016).

Abidin Nurdin, "Revitalisasi Kearifan Lokal Aceh: Peran Budaya dalam Menyelesaikan Konflik Masyarakat", dalam Jurnal Analisis, Vol. XIII, No. 1, (2013).

Arimbi Heroepoetri (peny.), Pengetahuan Hukum Sebagai Penberdayaan Hukum Perempuan: Hasil Pemantauan Akses Perempuan pada Keadilan, (Jakarta: Komnas Perempuan, 2011).

Azyumardi Azra, Surau Pendidikan Islam Tradisonal dalam Transisi dan Modernisasi, (Ciputat: Logos Wacvana Ilmu, 2003).

Badruzzaman Ismail, Masjid dan Adat Meunasah Sebagai Sumber Energi Budaya Aceh, (Banda Aceh: Majelis Adat Aceh Provinsi Nanggroe Aceh Darussalam, 2007).

Claudia Gracia-Moreno, WHO Multi-country Study on Women's Health and Domestic Violence agains Women: Initial Results on Prevalence, Health Outcomes and Women's Responses, (WHO Press, Geneva, 2005).

Emma Fulu, Why Do Some Men Use Violence Against Women and How We Can Preveni It?: Quantitative Finding From The United Nations Multi-Country Study on Men and Violence in Asia and The Pacific. (UNDP - UNFPA - UN Women and UNV, Bangkok, 2013). 
Husaini Husda, "Identifikasi Kearifan Lokal: Sistem Ketahanan dan Pengendalian Sosial Masyarakat di Kabupaten Nagan Raya", dalam Jurnal Adabiya, Vol. IX, No. 17, Agustus 2007, (Fakultas Adab IAIN Ar-Raniry, Darussalam-Banda Aceh, 2007).

Komnas Perempuan, Mewujudkan Perlindungan Perempuan Korban melalui Pemenuhan Bantuan Hukum: Kertas Posisi Terhadap Pembahasan RUU Bantuan Hukum.

Kristi Poerwandari, Peta Kekerasan: Pengalaman Perempuan Indonesia, (Komnas-Perempuan, Jakarta, 2002).

Mahdi, "Eksistensi Peradilan Adat di Aceh", dalam Jurnal Hunafa, Vol. 8, No. 2, (2011).

Moehammad Hoesein, Adat Atjeh, (Banda Aceh: Dinas Kebudayaan Provinsi Daerah Istimewa Aceh, 1970).

Mohammad Hakimi, Membisu Demi Harmoni, Kekerasan Terhadap Istri dan Kesehatan Perempuan di Jawa Tengah, Indonesia, (LPKGM FK UGM-Rifka Annisa WCCUmeaUniversity-Women's Health Exchange, Yogyakarta, 2001).

Naskur, "Hukum Islam dan Pranata Sosial: Sebuah Kajian Makna Teks Nash", dalam Jurnal alSyir'ah, Vol. I, No. 2, (2003).

Nurwani Idris, "Kedudukan Perempuan dan Aktualisasi Politik dalam Masyarakat Matrilinial Minangkabau”, dalam Jurnal Masyarakat, Kebudayaan, dan Politik, Tahun 25, No. 2, (2014).

Rusjdi Ali Muhammad dan Dedy Sumardi, Kearifan Tradisional Lokal: Penyerapan Syariat Islam dalam Hukum Adat Aceh, (Banda Aceh: Dinas Syariat Islam, 2011).

Sanday PR, "Matriarchal Value and World Peace: The Case of Minangkabau", dalam Second World Congress on Matriarchal Value, (Texas Austin, 2005).

Sidi Gazalba, Mesjid Pusat Ibadat dan Kebudayaan Islam, Cet. V, (Jakarta, Pustaka al-Husna, 1989).

Soerjono Soekanto, Pokok-pokok Sosiologi Hukum, (Jakarta: Rajawali Press, 1983).

Sunarso Siswanto, Viktimologi dalam Sistem Peradilan Pidana, (Jakarta: Sinar Grafika, 2012).

Syaiful Bahri dan Fajriani, "Suatu Kajian Awal Terhadap Tingkat Pelecehan Seksual di Aceh", dalam Jurnal Pencerahan, Vol. IX, No. 1, (2015).

Wisran Hadi, Sejarah Perkembangan Surau di Minangkabau, dalam Materi Pelatihan Pemberdayaan Gerakan Kembali Ke Surau dilaksanakan oleh Biro Peberdayaan Sospora Sekretaris Daerah Prov.Sumbar 15 2/d 17 Juli 2007 di Hotel Pangeran City, Padang. Bisa diakses pada www.geocities.ws/eyangcaca/31.pdf 